\title{
GIS-based assessment of combined AHP and SAW methods for selecting suitable sites for landfill in Al-Musayiab Qadhaa, Babylon, Iraq
}

\author{
Ali Jalil Chabuk ${ }^{1} \cdot$ Nadhir Al-Ansari $^{1} \cdot$ Hussain Musa Hussain $^{2} \cdot$ Sven Knutsson $^{1}$ • \\ Roland Pusch ${ }^{1}$
}

Received: 15 June 2016/ Accepted: 21 February 2017

(c) The Author(s) 2017. This article is published with open access at Springerlink.com

\begin{abstract}
Selecting a landfill site is a difficult task because the process depends on many factors and restrictions. Landfill is an optimal solution for the disposal of solid waste in Al-Musayiab Qadhaa, which is located in the northern part of Babylon Governorate. At the moment, there is no landfill site in that area that follows the scientific selection site criteria. For this reason, in this research, fifteen variables were considered (groundwater depth, rivers, soil types; agriculture lands use, land use, elevation, slope, gas pipelines, oil pipelines, power lines, roads, railways, urban centers, villages and archeological sites) using geographic information system (GIS) to find out the best suitable landfill site. In addition, two methods of multicriteria decision-making were used to derive weights for criterion's maps on GIS to obtain potential landfill sites. The first method is analytical hierarchy process (AHP) which was used to identify the weight for each criterion from the matrix of pairwise comparisons. The second
\end{abstract}

Nadhir Al-Ansari

nadhir.alansari@1tu.se

Ali Jalil Chabuk

ali.chabuk@1tu.se

Hussain Musa Hussain

humhudhy02@gmail.com

Sven Knutsson

Sven.Knutsson@1tu.se

Roland Pusch

drawrite.se@gmail.com

1 Department of Civil Environmental and Natural Resources Engineering, Lulea University of Technology, 97187 Lulea, Sweden

2 Department of Geology, Faculty of Science, University of Kufa, Kufa, Iraq method was the simple additive weighting (SAW) which is a simple method to solve the problem of the selection landfill sites. After comparison of the results obtained based on combining two final maps resulted from methods of AHP and SAW using GIS environment to determine the pixels percentage of matching and non-matching for two maps, two suitable candidate landfill sites were identified that satisfy the requirements with an area of $7.965-5.952 \mathrm{~km}^{2}$. Area of these sites can accommodate the solid waste generated from the Qadhaa up to 2030.

Keywords Landfill · Al-Musayiab Qadhaa · AHP · SAW · Combine maps assessment

\section{Introduction}

In developing countries, choosing an appropriate sanitary site for landfill to get rid of solid waste is the most costeffective system for most urban areas. Such a decision needs extensive process for the evaluation of the lands in order to determine the proper place for disposal of solid waste optimally. This site must conform to environmental and scientific requirements and governmental regulations in any country. It should also reduce economic, environmental, health and social effects and cost when selecting a landfill (Siddiqui et al. 1999). Lately, solid waste management became an urgent need as a result of increasing environmental problems in urban areas. Therefore, there is a tendency to select or design a landfill site to increase the protection of the environment in those areas and their surrounding (Nas et al. 2010). There are many factors to be taken into account in the process of identifying landfill sites, where the combination of these factors in the selection process is a complex task. These factors include social, 
environmental, technical and economic considerations. Economic factors comprise the costs associated by purchasing lands, operation and development of the site. For this reason, they have an important role in the landfill selection process (Delgado et al. 2008; Yesilnacar and Cetin 2008). Environmental factors must be considered where landfill might have an adverse effect on the environment of the surrounding area (Kontos et al. 2003; Siddiqui et al. 1999; Lober 1995). The biggest obstacle to identify the most suitable locations for landfill is social and political opposition for these locations, which cause tremendous pressure on the decision makers in the process of selecting suitable sites for landfills (Chang et al. 2007; Kontos et al. 2003; Lin and Kao 1999). Cost of transportation is also an important factor because far distance from the main roads and waste production centers to landfill causes additional cost on the beneficiary's budget (Wang et al. 2009). In the process of taking decision regarding selecting landfill site, many factors should be incorporated into ideal technological geographic approaches that allow the integration of multialternatives in its environment. Geographic information system (GIS) is one of these approaches, which have high ability to manage large volumes of spatial data and simulate necessary effect factors from variety of sources (Şener et al. 2011; Delgado et al. 2008; Kontos et al. 2003). In order to derive weights for criteria maps and use them in the GIS to get on a suitable site for landfill, many methods of multi-criteria decision-making can be used. Analytical hierarchy process (AHP) and simple additive weighting (SAW) are examples of such methods. AHP was originally developed by Thomas Saaty in 1980. It is one of the methods used for taking a decision for multi-criteria variables, where it reduces complex decisions to a series of pairwise comparisons and consistency. The results are given in a matrix of pairwise comparison. Simple additive weighting (SAW) is considered a real application that depends on personal decision using the experts' opinion of the decision-making model (Afshari et al. 2010).

This study focuses on selecting suitable candidate sites for landfills through inserting multi-criteria in GIS for AlMusayiab Qadhaa in Babylon Governorate, Iraq, using AHP and SAW. In addition, the results of the two methods are compared to select the most suitable site.

\section{Methodology}

\section{The study area}

Al-Musayiab Qadhaa is considered as one of the major Babylon Governorate provinces. It is located in the northern part of this governorate (longitude $44^{\circ} 2^{\prime} 43^{\prime \prime} \mathrm{E}$ and $44^{\circ} 29^{\prime} 32^{\prime \prime} \mathrm{E}$, and latitude $32^{\circ} 31^{\prime} 50^{\prime \prime} \mathrm{N}$ and $33^{\circ} 7^{\prime}$ $36^{\prime \prime} \mathrm{N}$ ) (Fig. 1). It consists of four districts which are AlMusayyab, Al-Sadah, Al-Iskandariyah and Jurf Al-Sakhar.

The area of Al-Musayiab Qadhaa is $1008 \mathrm{~km}^{2}$, which represents $18.9 \%$ of the total area of the Babylon Governorate (Iraqi Ministry of Municipalities and Public Works 2009). Its population is 397,425 inhabitants in 2015 (Iraqi Ministry of Planning 2015) which represent $18.97 \%$ of the total population in the governorate.

\section{Creation the tree of the decision process for landfill siting}

Many researchers exerted hard effort in their researches in the process of site selection by adopting many approaches and depending on nature of factors and criteria available in each country.

In this work previous research, opinions of many experts in this field and data available about the study area (e.g., maps of the criteria, database for groundwater, quantity of solid waste, environmental factors, social factors, cultural factors, etc.) were used. Accordingly, the hierarchical structure of the decision problem of site selection for landfill in Al-Musayiab Qadhaa was constructed. It includes three levels as shown in Fig. 2. The first level includes two broad categories which are natural environmental and artificial factors. The second level comprises six main groups of factors. They are: hydrological, land, topographical, infrastructure, accessibility and social-cultural factors. The third level consists of all criteria ( 15 criterions), which were used in this study to get the suitable candidate sites for the landfill. These criteria are groundwater depth, rivers, soil types; agriculture lands use, land use, elevation, slope, gas pipelines, oil pipelines, power lines, roads, railways, urban centers, villages and archeological sites.

\section{Maps selected for the used criteria}

Individual maps (topography, slope, river, road, urban centers, villages, gas pipelines, oil pipelines, power lines and railways) were obtained, and shape files were prepared accordingly using the internal reports of the Iraqi Ministry of Education. To create the shape file of groundwater depths, data for 170 wells (Iraqi Ministry of Water Resources 2015) were entered into GIS software to generate interpolation between them using the spatial extension tool known as Kriging. For preparing the shape file of "Agricultural land use", land capability map of Iraq (scale 1:1,000,000) was used (Iraqi Ministry of Water Resources 1990). It was then checked through analyzing the satellite images of Babylon Governorate dated 2011 (Iraqi Ministry of Municipalities and Public Works 2011). The relevant information was obtained 


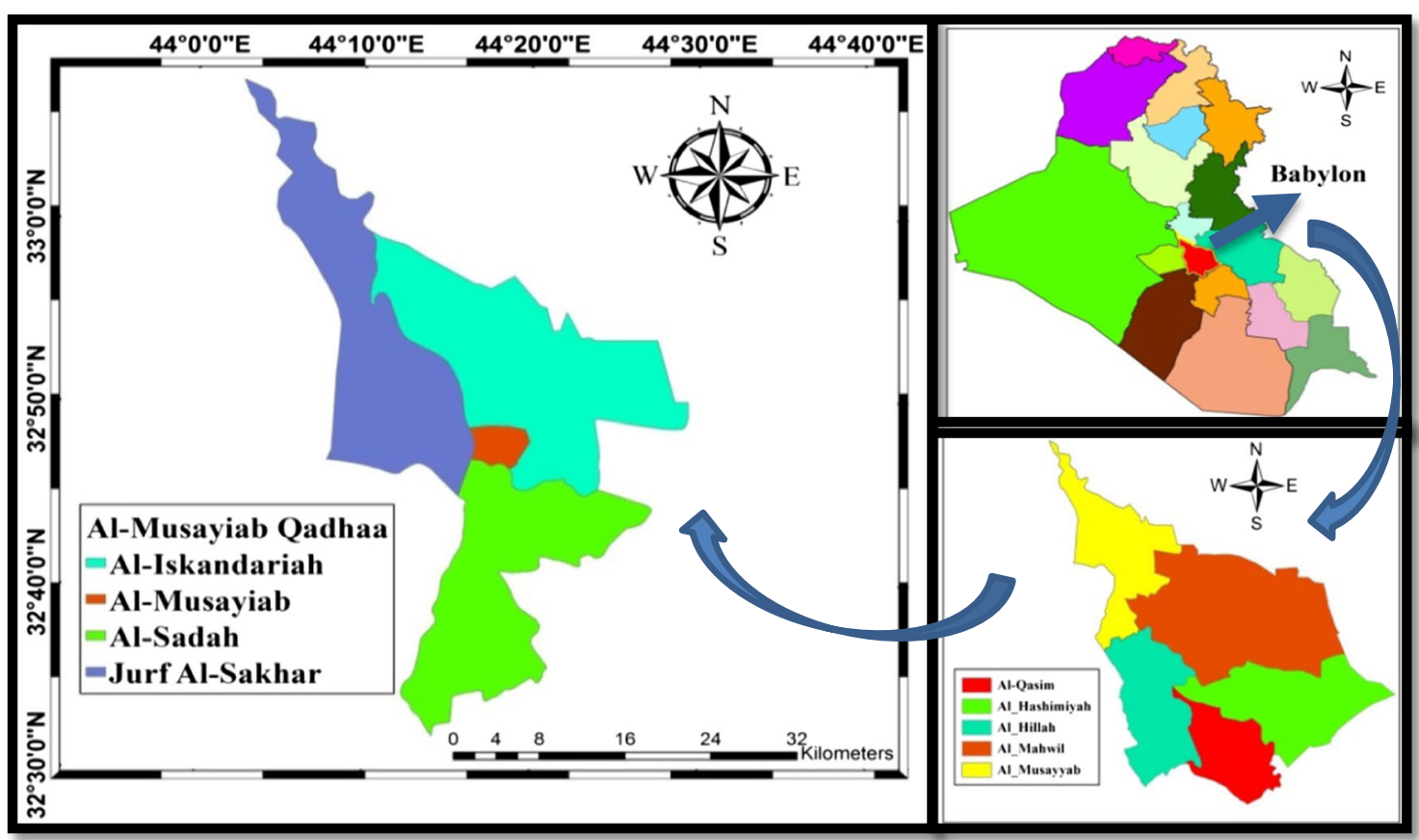

Fig. 1 Map of Al-Musayiab Qadhaa

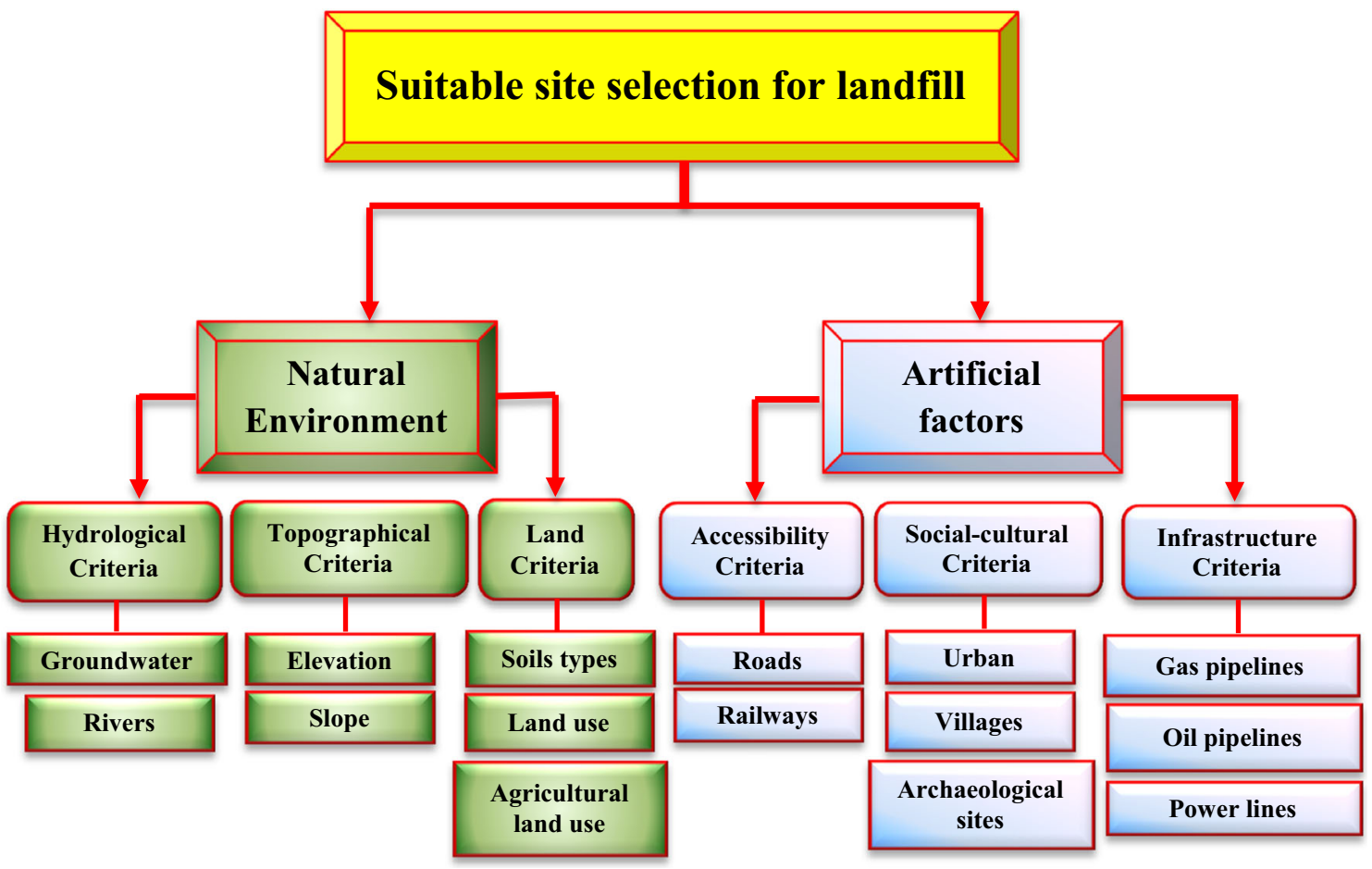

Fig. 2 Tree diagram of the decision process developed for selection of suitable landfill sites

using in archeological sites map (scale 1:1,500,000) (The Archaeological Map of Iraq 2013), industrial areas map (scale 1:400,000) (Iraqi Ministry of Municipalities and Public Works 2011) and the exploratory soil map (scale
1:1,000,000) (Buringh 1960). The information was then used within GIS using its spatial analyst tools (as a separate shape file) in each map, and then they were converted to the raster maps. 


\section{Input data}

There were many steps that were performed in GIS in order to get the final required layers in this study (e.g., Buffer, Clip, Extract, Overlay, Proximity, Convert, Reclassify and Map Algebra, etc.). In GIS, each criterion was classified into classes, and each class was given a suitability score value based on view of experts and previous literature in this field, as shown in Table 1 . In each criterion, it a buffer zone was created from or around an important site or geographic feature, and then the map of studied area was divided into zones to suit every criterion map within the GIS environment. The resulting buffer maps were converted to raster maps. For "groundwater depth" layer, potential sites were given a rating according to groundwater depth readings. A depth between 0-2.5, 2.5-5, 5-7.5, $7.5-10 \mathrm{~m}$ and more than 10 to groundwater was given grades values of 1, 2, 4, 6, and 10, respectively (Fig. 3a). For rivers, the buffer zone was considered less than $1000 \mathrm{~m}$, from river boundary. The grading was given a value of zero in order to protect surface water from contamination, as shown in Fig. 3b. For the topography (Fig. 3c), elevations between 23 and $30 \mathrm{~m}$ above mean sea level (a.m.s.l.) were deemed moderately suitable, between 30 and $37 \mathrm{~m}$ (a.m.s.l.) were suitable and elevations greater than $37 \mathrm{~m}$ (a.m.s.1.) were the most suitable. These categories of elevation map layer were given values of 3, 7 and 10 respectively. For "Slope" layer, all the land in the study area has a slope of $0^{\circ}-5^{\circ}$ and was given a rating value of 10 (Fig. 3d). For the layer of "Soil Types", there are six types of soils in Al- Musayiab Qadhaa (Buringh 1960). They are: Basin Depression Soils 6 (A), River basin soils, poorly drained phase $5^{\prime}$ (B), River Basin Soils, poorly drained phase 5 (C), River Levee Soils 4 (D), Mixed Gypsiferous Desert Land 17 (E), Sand Dune Land 18 (F) and Gypsiferous Gravel Soils 1 (G). After merging all these categories in single layer, this layer was converted to a raster layer. These types were given grades of 10, 9, 8, 7, 3, 2 and 1, respectively (Fig. 3e). More details about these types are given by (Chabuk et al. 2016). The layer "Land Use" of the study area was classified into one of eight categories: urban centers, villages, industrial areas, archeological sites, rivers, agricultural land, orchards and unused land. The categories' orchards and unused lands were given ratings of 5 and 10, respectively, whereas other categories were assigned a score of zero (Fig. 3f). For "Agricultural land use" (Fig. 3g), the layer was divided into three categories: agricultural land, orchards and unused land. Agricultural land, orchards and unused land were given grades value of zero, 5 and 10, respectively. The layer of "Roads" included the main roads and highways. In this study, buffer zones from roads to landfill sites were classified to 4 categories (less than $500 \mathrm{~m}, 500-1000 \mathrm{~m}, 2000-3000 \mathrm{~m}$ and greater than $3000 \mathrm{~m}$ ). These were given scores of zero, 7, 5 and 3, respectively. Buffer zones of 1000-2000 m were assigned the highest score of 10 (Fig. 3h). In "Railway" layer, buffer zones of less than $500 \mathrm{~m}$ on both sides were given a score of zero (Fig. 3i). For "Urban Centers" layer, a buffer zone less than $5 \mathrm{~km}$ around the borders of urban centers to landfill was given a score of zero and buffer zones between of 5 and $10 \mathrm{~km}$ were given the highest score (10). Buffer zones between 10 to $15 \mathrm{~km}$ and more than $15 \mathrm{~km}$ were given scores value of 7 and 4 , respectively (Fig. $3 j$ ). For the "villages" layer, buffer zones less than $1000 \mathrm{~m}$ were given a grading value of zero (Fig. 3k). In the "Archeological Sites" layer, buffer zones more than $3 \mathrm{~km}$ around these areas were scored 10 . Buffer zones of $1-3 \mathrm{~km}$ were scored 5 , while buffer zones of $\leq 1 \mathrm{~km}$ around these areas were excluded (scored zero) (Fig. 31). The buffer zones from Gas pipelines, oil pipelines and power lines to a landfill site were taken in this study as 300,75 and $30 \mathrm{~m}$ on both sides. Thereby, it was given a grading value of zero. Distances more than these limits they were given a score value of 10 (Fig. 3m, n, o).

\section{Methods of analysis process}

After preparing all criteria within GIS, and then in order to get suitable landfill candidate sites for in Al-Musayiab Qadhaa, two methods were adopted to derive weights for criteria. They were used in the application of spatial extension tool "Map Algebra" in GIS to produce the final output map for suitability index for landfill site after implementing the comparison between these two methods. This was achieved as follows:

\section{Simple Additive Weighting (SAW) method}

Simple additive weighting (SAW), also defined as weighted linear combination or scoring method, is considered as a simple method that uses multi-attribute decision technique. It is based on experts' opinion to derive the weight for each criterion, as well as selecting the importance and weight of each criterion relative to other criterion in this study. There are two assumptions in the SAW method of additivity and linearity. These assumptions are very difficult to apply to solve real problems. In linearity assumption, any additional unit to an attribute remains constant at any level of that attribute, while in additivity assumption there is no interaction or no effect between the layers (Şener et al. 2006; Şener 2004). In this study, serious attempt was carried out to strongly complement between criteria layers. The advantage of such method is that it is a proportional linear transformation of the raw data. This means that the relative order of magnitude of the standardized scores will be kept equal (Afshari et al. 2010). 
Table 1 Summary of the input layers used in the analysis

\begin{tabular}{|c|c|c|c|c|c|c|}
\hline No. & criterion & Buffer zone & Rating & $\begin{array}{l}\text { Normalized } \\
\text { weights } \\
\text { AHP }\end{array}$ & $\begin{array}{l}\text { Weights and normalized } \\
\text { weights } \\
\text { SAW }\end{array}$ & Suggested buffers \\
\hline 1 & $\begin{array}{l}\text { Groundwater depth } \\
\text { (m) }\end{array}$ & $\begin{array}{l}0-2.5 \\
2.5-5 \\
5-7.5 \\
7.5-10 \\
>10\end{array}$ & $\begin{array}{r}1 \\
2 \\
4 \\
6 \\
10\end{array}$ & 0.2004 & (10) 0.111 & $\begin{array}{l}6 \mathrm{~m} \text { (Effat and Hegazy 2012); } \\
10 \mathrm{~m} \text { (Delgado et al. 2008); } \\
30 \mathrm{~m} \text { (Sadek et al. 2006) }\end{array}$ \\
\hline 2 & Rivers (m) & $\begin{array}{l}0-1000 \\
>1000\end{array}$ & $\begin{array}{r}0 \\
10\end{array}$ & 0.1471 & (9) 0.1 & $\begin{array}{l}1 \mathrm{~km} \text { (Kara and Doratli 2012; } \\
\text { Eskandari et al. 2012); } \\
0.8 \text { km (Siddiqui et al. 1999) }\end{array}$ \\
\hline 3 & Elevation (a.m.s.l.) & $\begin{array}{l}23-30 \\
30-37 \\
>37\end{array}$ & $\begin{array}{r}3 \\
7 \\
10\end{array}$ & 0.0709 & (7) 0.078 & \\
\hline 4 & Slope (degree) & $0-5^{\circ}$ & 10 & 0.0463 & (6) 0.067 & $\begin{array}{l}0^{\circ}-5^{\circ} \text { (Effat and Hegazy 2012; } \\
\text { Ersoy and Bulut 2009) }\end{array}$ \\
\hline 5 & Soils types & $\begin{array}{l}\text { Soil } 1(\mathrm{G}) \\
\text { Soil } 18(\mathrm{~F}) \\
\text { Soil } 17(\mathrm{E}) \\
\text { Soil } 4(\mathrm{D}) \\
\text { Soil } 5(\mathrm{C}) \\
\text { Soil } 5^{\prime}(\mathrm{B}) \\
\text { Soil } 6(\mathrm{~A})\end{array}$ & $\begin{array}{r}1 \\
2 \\
3 \\
7 \\
8 \\
9 \\
10\end{array}$ & 0.0709 & (7) 0.078 & \\
\hline 6 & Land use & $\begin{array}{l}\text { Industrial areas } \\
\text { Urban centers } \\
\text { Villages } \\
\text { Rivers } \\
\text { Archeological } \\
\text { sites } \\
\text { Agricultural } \\
\text { lands } \\
\text { Orchards } \\
\text { Unused lands }\end{array}$ & $\begin{array}{r}0 \\
0 \\
0 \\
0 \\
0 \\
0 \\
\\
5 \\
10\end{array}$ & 0.0302 & (5) 0.056 & \\
\hline 7 & Agricultural land use & $\begin{array}{l}\text { Agriculture lands } \\
\text { Orchards } \\
\text { Unused lands }\end{array}$ & $\begin{array}{r}0 \\
5 \\
10\end{array}$ & 0.0462 & (6) 0.067 & \\
\hline 8 & Roads (m) & $\begin{array}{l}0-500 \\
500-1000 \\
1000-2000 \\
2000-3000 \\
>3000\end{array}$ & $\begin{array}{r}0 \\
7 \\
10 \\
5 \\
3\end{array}$ & 0.0463 & (6) 0.067 & $\begin{array}{l}1 \mathrm{~km} \text { (Kara and Doratli 2012; } \\
\text { Sharifi et al. 2009); } 0.5 \mathrm{~km} \\
\text { (Şener et al. 2006) }\end{array}$ \\
\hline 9 & Railways (m) & $\begin{array}{l}0-500 \\
>500\end{array}$ & $\begin{array}{r}0 \\
10\end{array}$ & 0.0107 & (2) 0.022 & $\begin{array}{l}500 \mathrm{~m} \text { (Demesouka et al. 2013; } \\
\text { Wang et al. 2009) }\end{array}$ \\
\hline 10 & Urban centers $(\mathrm{m})$ & $\begin{array}{l}0-5000 \\
5000-10,000 \\
10,000-15,000 \\
>15,000\end{array}$ & $\begin{array}{r}0 \\
10 \\
7 \\
4\end{array}$ & 0.1471 & (9) 0.1 & $\begin{array}{l}5 \text { km (Isalou et al. 2013; Sener } \\
\text { 2004); } 3 \text { km (Chang et al. } \\
\text { 2007) }\end{array}$ \\
\hline 11 & Villages (m) & $\begin{array}{l}0-1000 \\
>1000\end{array}$ & $\begin{array}{r}0 \\
10\end{array}$ & 0.1038 & (8) 0.089 & $\begin{array}{l}1 \mathrm{~km} \text { (Şener et al. 2006; } \\
\text { Charnpratheep et al. 1997). }\end{array}$ \\
\hline
\end{tabular}


Table 1 continued

\begin{tabular}{|c|c|c|c|c|c|c|}
\hline No. & criterion & Buffer zone & Rating & $\begin{array}{l}\text { Normalized } \\
\text { weights } \\
\text { AHP }\end{array}$ & $\begin{array}{l}\text { Weights and normalized } \\
\text { weights } \\
\text { SAW }\end{array}$ & Suggested buffers \\
\hline 12 & $\begin{array}{l}\text { Archeological sites } \\
\text { (m) }\end{array}$ & $\begin{array}{l}0-1000 \\
1000-3000 \\
>3000\end{array}$ & $\begin{array}{r}0 \\
5 \\
10\end{array}$ & 0.0302 & (5) 0.056 & $\begin{array}{l}1 \mathrm{~km} \text { (Ersoy and Bulut 2009; } \\
\text { Gupta et al. 2003); 0.5 km } \\
\text { (Eskandari et al. 2012) }\end{array}$ \\
\hline 13 & Gas pipelines (m) & $\begin{array}{l}\leq 250 \\
>250\end{array}$ & $\begin{array}{r}0 \\
10\end{array}$ & 0.0146 & (3) 0.033 & 250 m (Uyan 2014) \\
\hline 14 & Oil pipelines $(\mathrm{m})$ & $\begin{array}{l}\leq 100 \\
>100\end{array}$ & $\begin{array}{r}0 \\
10\end{array}$ & 0.0146 & (3) 0.033 & 250 m (Uyan, 2014) \\
\hline 15 & Power lines (m) & $\begin{array}{l}\leq 30 \\
>30\end{array}$ & $\begin{array}{r}0 \\
10\end{array}$ & 0.0207 & (4) 0.044 & $\begin{array}{l}30 \mathrm{~m} \text { (Yildirim 2012; Şener } \\
\text { et al. 2006); } 40 \mathrm{~m} \text { (Sadek } \\
\text { et al. 2006) }\end{array}$ \\
\hline
\end{tabular}

$A H P$ analytical hierarchy process; a.m.s.l.: above mean sea level; $S A W$ simple addictive weighing method

This method is based on the weighted average. The score can be calculated for each alternative by multiplying the normalized weight of relative importance for each criterion (which is assigned by the decision maker) by the standardized rating value of subcriterion scale drange for each criterion. Finally, the products for all attribute are summed up. In the beginning, set of evaluation criteria (map layers and the set of feasible alternatives) were defined in the GIS based on simple additive weighting method (Şener 2004). In this study, fifteen map layers of necessary criteria were taken into consideration in the process of landfill site selection. The weights of the criteria were normalized to generate the score for each criterion (Table 1). These weights were then converted into map forms using the spatial extensions tool of "Map Algebra" in GIS environment. This helped to create the final output map of landfill suitability using SAW method.

The mathematical formulation to evaluate each alternative $\left(S_{i}\right)$ using the simple additive weighting method was as follows (Eskandari et al. 2012; Afshari et al. 2010):

$S_{i}=\sum_{j=1}^{n} W_{j} \times N_{i j}$

where: $S_{i}$ : suitability index for area $i ; W_{j}$ : relative importance of normalized weight of criterion (attribute); $N_{i j}$ : the standardized rating value of area $i$ under criterion $j$; and $n$ : number of criteria.

For the suitability of the selected landfill sites, the final output map was divided into five categories, including the category of restricted areas for landfill siting, where the category was restricted only from the final output map, and it covered areas of $60.9 \mathrm{~km}^{2}(6.87 \%)$ with a zero value. Other categories were classified according to the area related to each classification and its proportion of the total study area. These classifications are "unsuitable", "moderately suitable", "suitable" and "most suitable"; they covered areas of
Fig. 3 Suitability index maps of a Ground water depth; b Rivers; c Elevation; d Slope; e Soil types; f Land use; g Agricultural land use; h Roads; i Railways; j Urban centers; k Villages; I Archeological sites; m Gas pipelines; $\mathbf{n}$ Oil pipelines; o Power lines

$24.1 \mathrm{~km}^{2}(2.71 \%), 191.3 \mathrm{~km}^{2}(21.6 \%), 384.5 \mathrm{~km}^{2}(43.42 \%)$ and $225.2 \mathrm{~km}^{2}(25.4 \%)$, respectively (Fig. $4 \mathrm{a}$ ).

\section{Analytical Hierarchy Process (AHP)}

The analytical hierarchy process (AHP) is one of the most common methods in multi-criteria decision-making that was proposed by Saaty 1980. It decomposes a complex decision problem into simpler decision problems to form a hierarchy of decision. AHP is a comprehensive and powerful methodology and aims to facilitate making the right decision through the use of each of subjective judgments of the decision maker as well as empirical data. It combines materialistic and non-materialistic aspects in order to derive weights for the criteria (Rezaei-Moghaddam and Karami 2008). AHP method is based primarily on pairwise comparisons rather than assessing scores and weights directly for the criteria, where this method allows some small inconsistency in judgment because human is not always consistent in his decisions (Teknomo 2006). In typical analytic hierarchy, the numerical scale of 9-point is used. Each point equates to an expression of the relative importance of two factors, e.g., "A has the same importance of B" or " $\mathrm{A}$ is more important than B", etc. These studies use a scale with values ranging from 1 (equal importance or no difference) to 9 (absolute importance or extreme preference) (Hussain 2004; Saaty 1980) (Table 2).

For calculating the weights of the criteria, this involves calculating the eigenvectors $\left(\mathrm{Eg}_{\mathrm{i}}\right)$ for each row based on multiplying the value for each criterion in each column in the same row in the matrix of the pairwise comparison and putting the output value under the root for numbers of elements in this 


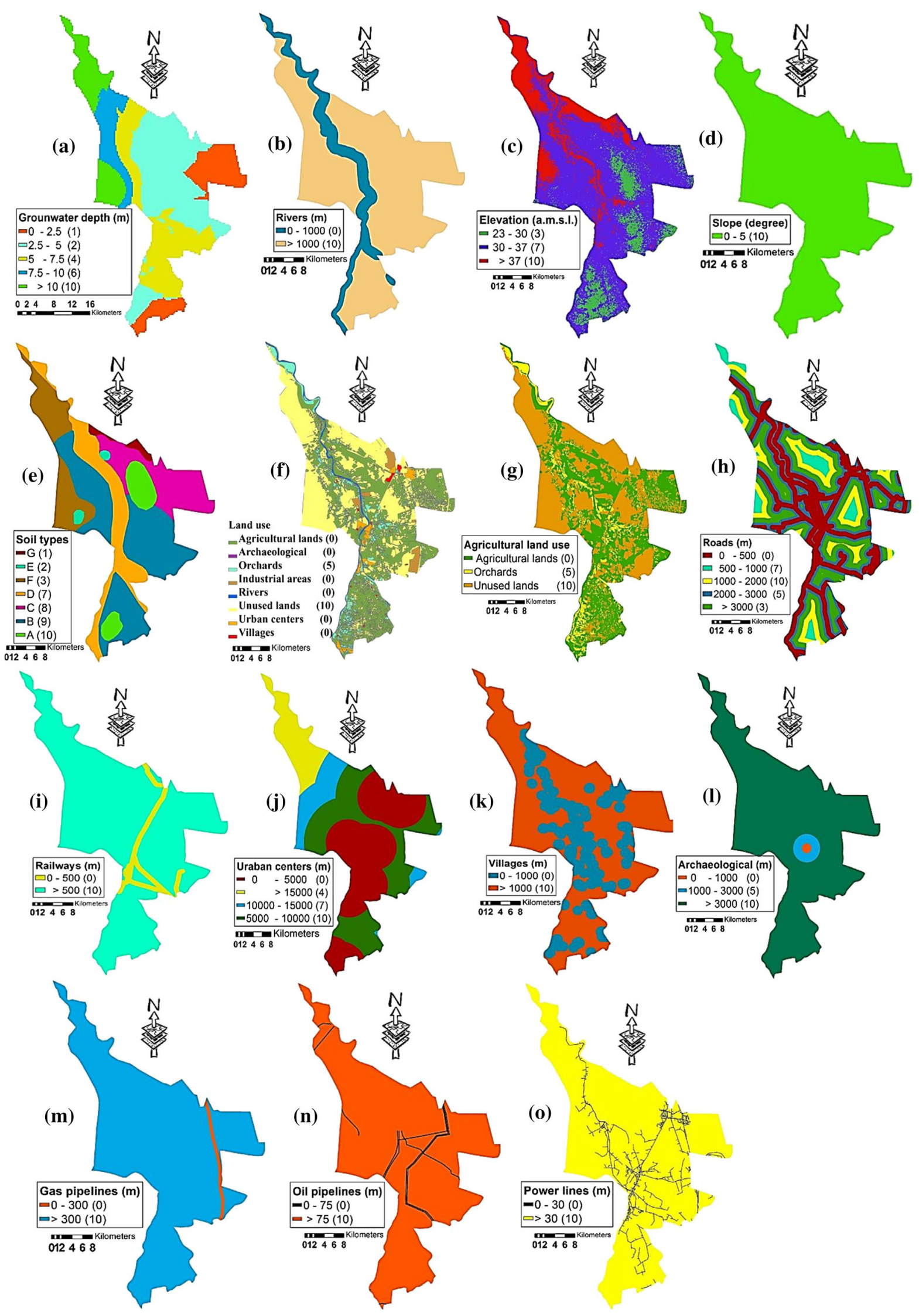



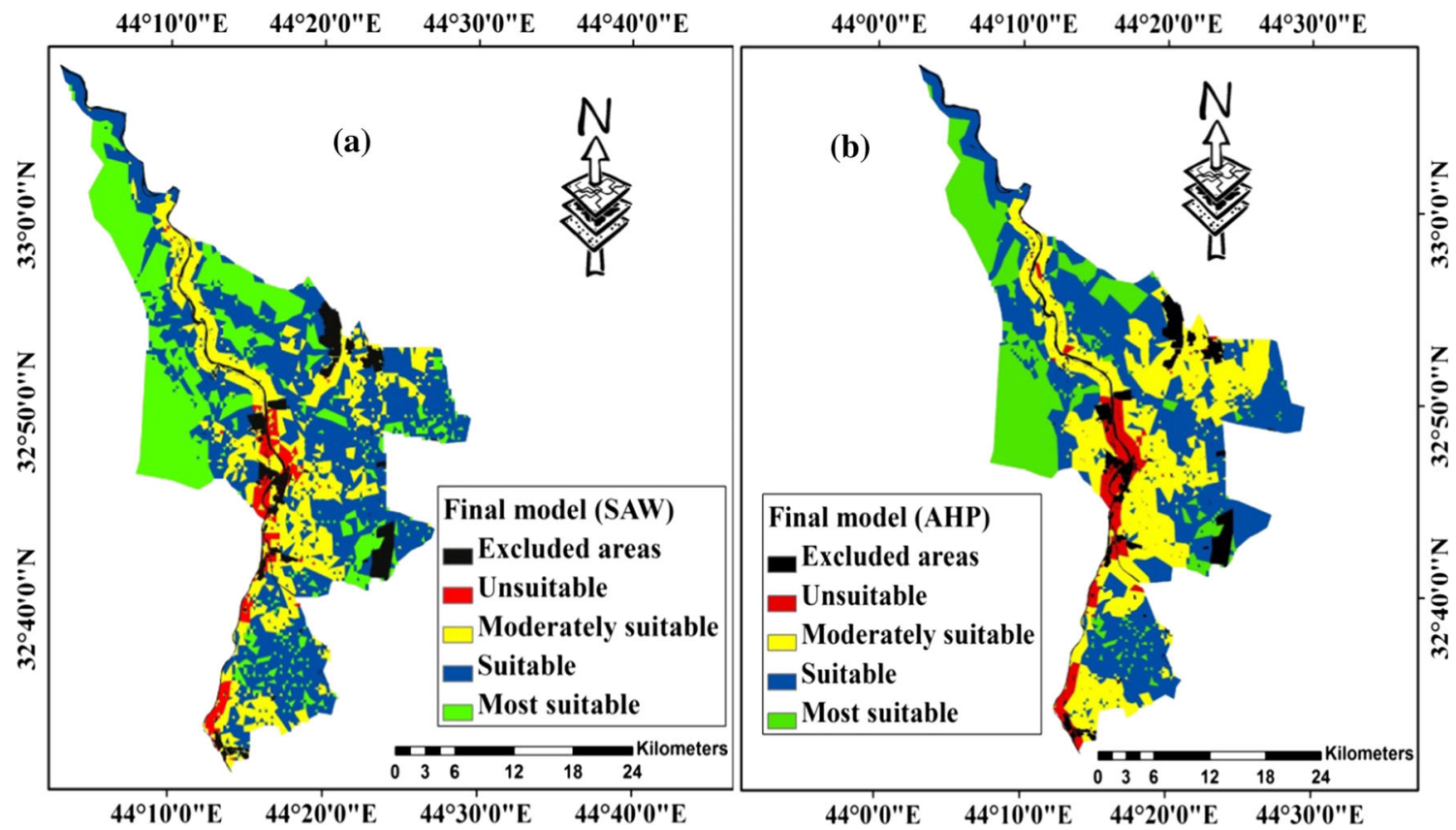

Fig. 4 Final model maps of a suitability landfill of Al-Musayiab Qadhaa using a (SAW); b (AHP)

row and then applying this to each row (Fig. 5). Then eigenvalue is normalized to 1 through dividing each weight by their sum, and this is known as the priority vector or normalized weights $\left(\mathrm{Pr}_{\mathrm{i}}\right)$. In order to determine whether the comparisons between criteria in a matrix of pairwise comparisons are consistent, this is done through estimating the consistency ratio which involve the following procedure:

After computing the eigenvalue and the priority vector, the lambda max $\left(\lambda_{\max }\right)$ is obtained from the summation of products of multiplying the sum of each column of the matrix by the corresponding value of the priority vector. Then, the consistency index $\left(\mathrm{CI}=\left(\lambda_{\max }-\mathrm{n} / \mathrm{n}-1\right)\right)$ is estimated which represents the equivalent to the mean deviation of each comparison element and the standard deviation of the evaluation error from the true ones (Solnes 2003). In this study, the value of $\left(\lambda_{\max }\right)$ and $(\mathrm{CI})$ were 15.612 and 0.044 , respectively. Calculation of the consistency ratio $(\mathrm{CR}=\mathrm{CI} / \mathrm{RI})$ which is obtained according to (Saaty 1980), by dividing the value of consistency index (CI) by the Random index value (RI), where RI is the mean deviation of randomly for matrices with different size (Table 3).

If the value of consistency ratio is smaller or equal to 0.1 , then the inconsistency is acceptable. In this study, CR was $0.027<0.1$ and $\mathrm{RI}_{15}$ was 1.59 . For any matrix, the judgments are completely consistent if CR is equal to zero (Coyle 2004). More details about the application of all the equations used in AHP were given by Chabuk et al. (2016), Şener et al. (2011).

The final output map of landfill suitability that was created in GIS using AHP method was reclassified into five categories.
Table 2 Scale of relative importance for pairwise comparison (Saaty 1980)

\begin{tabular}{ll}
\hline Intensity of importance & Definition \\
\hline 1 & Equal importance \\
2 & Equal to moderately importance \\
3 & Moderate importance \\
4 & Moderate to strong importance \\
5 & Strong importance \\
6 & Strong to very strong importance \\
7 & Very strong importance \\
8 & Very to extremely strong importance \\
9 & Extreme importance \\
\hline
\end{tabular}

These categories are "unsuitable", "moderately suitable", "suitable", "most suitable" and "excluded areas" (urban centers, villages, rivers, archeological sites and industrial areas). They cover areas of $35.7 \mathrm{~km}^{2}(4.03 \%), 268.9 \mathrm{~km}^{2}$ (30.34\%), $343.2 \mathrm{~km}^{2}(38.72 \%) \quad 177.6 \mathrm{~km}^{2}(20.04 \%)$ and $60.9 \mathrm{~km}^{2}(6.87 \%)$, respectively. It should be mentioned, however, that the fifth category was restricted only from the final output map and was given a value of zero (Fig. 4b).

\section{Comparison of the results from the two methods used}

In order to compare the resultant maps obtained from the two methods (SAW and AHP), each map was classified into four categories, where the excluded areas were 


\begin{tabular}{|c|c|c|c|c|c|c|c|c|c|c|c|c|c|c|c|c|c|}
\hline Criteria & 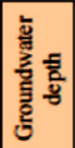 & 온 & 总 & $\frac{\frac{2}{3}}{2}$ & 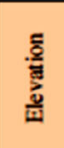 & $\frac{8}{\frac{8}{5}}$ & 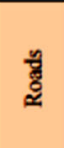 & $\begin{array}{l}\frac{n}{2} \\
\frac{n}{5} \\
\frac{n}{0}\end{array}$ & $\frac{\stackrel{B}{E}}{\frac{5}{\bar{n}}}$ & $\frac{\frac{\mathscr{E}}{\bar{x}}}{\frac{\bar{\alpha}}{\overline{0}}}$ & 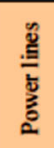 & 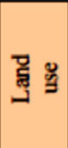 & 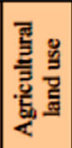 & 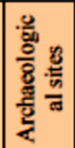 & 䌟 & 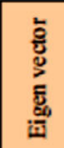 & 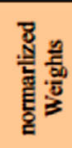 \\
\hline Groundwater depth & 1 & 2 & 3 & 2 & 4 & 5 & 5 & 4 & 8 & 8 & 7 & 6 & 5 & 6 & 9 & 4.33 & 0.2004 \\
\hline Urban centers & 0.50 & 1 & 2 & 1 & 3 & 4 & 4 & 3 & 7 & 7 & 6 & 5 & 4 & 5 & 8 & 3.18 & 0.1471 \\
\hline Villages & 0.33 & 0.50 & 1 & 0.5 & 2 & 3 & 3 & 2 & 6 & 6 & 5 & 4 & 3 & 4 & 7 & 2.24 & 0.1038 \\
\hline Rivers & 0.50 & 1.00 & 2.00 & 1 & 3 & 4 & 4 & 3 & 7 & 7 & 6 & 5 & 4 & 5 & 8 & 3.18 & 0.1471 \\
\hline Elevation & 0.25 & 0.33 & 0.50 & 0.33 & 1 & 2 & 2 & 1 & 5 & 5 & 4 & 3 & 2 & 3 & 6 & 1.53 & 0.0709 \\
\hline Slope & 0.20 & 0.25 & 0.33 & 0.25 & 050 & $\frac{2}{1}$ & 1 & 0.5 & 4 & 4 & 3 & 2 & 1 & 2 & 5 & 1.00 & 0.0463 \\
\hline Roads & 0.20 & 0.25 & 0.33 & 0.25 & 0.50 & 1.00 & 1 & 0.5 & 4 & 4 & 3 & 2 & 1 & 2 & 5 & 1.00 & 0.0463 \\
\hline Soils types & 0.25 & 0.33 & 0.50 & 0.33 & 1.00 & 2.00 & 2.00 & 1 & 5 & 5 & 4 & 3 & 2 & 3 & 6 & 1.53 & 0.0709 \\
\hline Gas pipelines & 0.13 & 0.14 & 0.17 & 0.14 & 0.20 & 0.25 & 0.25 & 0.20 & 1 & 1 & 0.5 & 0.34 & 0.25 & 0.34 & 2 & 0.32 & 0.0146 \\
\hline Oil pipelines & 0.13 & 0.14 & 0.17 & 0.14 & 0.20 & 0.25 & 0.25 & 0.20 & 1.00 & I & 0.5 & 0.34 & 0.25 & 0.34 & 2 & 0.32 & 0.0146 \\
\hline Power lines & 0.14 & 0.17 & 0.20 & 0.17 & 0.25 & 0.33 & 0.33 & 0.25 & 2.00 & 2.00 & 1 & 0.5 & 0.34 & 0.5 & 3 & 0.45 & 0.0207 \\
\hline Land use & 0.17 & 0.20 & 0.25 & 0.20 & 0.33 & 0.50 & 0.50 & 0.33 & 2.94 & 2.94 & 2.00 & 1 & 0.5 & 1 & 4 & 0.65 & 0.0302 \\
\hline Agricultural land use & 0.20 & 0.25 & 0.33 & 0.25 & 0.50 & 1.00 & 1.00 & 0.50 & 4.00 & 4.00 & 2.94 & 2.00 & 1 & 2 & 5 & 1.00 & 0.0462 \\
\hline Archaeological sites & 0.17 & 0.20 & 0.25 & 0.20 & \begin{tabular}{|l|}
0.33 \\
\end{tabular} & 0.50 & 0.50 & 0.33 & 2.94 & 2.94 & 2.00 & 1.00 & 0.50 & 1 & 4 & 0.65 & 0.0302 \\
\hline Railways & 0.11 & 0.13 & 0.14 & 0.13 & 0.17 & 0.20 & 0.20 & 0.17 & 0.50 & 0.50 & 0.33 & 0.25 & 0.20 & 0.25 & 1 & 0.23 & 0.0107 \\
\hline
\end{tabular}

Fig. 5 Pairwise comparisons matrix for selecting suitable landfill site, Eigenvector and Significance weights

Table 3 Random inconsistency indices for different values of (n) (Saaty 1980; Chang et al. 2007)

\begin{tabular}{llrlll}
\hline$(n)$ & RI & $(n)$ & RI & $(n)$ & RI \\
\hline 1 & 0 & 6 & 1.24 & 11 & 1.51 \\
2 & 0 & 7 & 1.32 & 12 & 1.48 \\
3 & 0.58 & 8 & 1.41 & 13 & 1.56 \\
4 & 0.9 & 9 & 1.45 & 14 & 1.57 \\
5 & 1.12 & 10 & 1.49 & 15 & 1.59 \\
\hline
\end{tabular}

omitted. The four categories with their figures were: unsuitable (1), moderately suitable (2), suitable (3) and most suitable (4). The suitability index and number of pixels from the final maps of these methods are shown in Fig. 6. For purpose of comparison between the two methods, the final maps were entered again in GIS using the spatial analysis tool "Map Algebra" through applying the formula "Combine (AHP raster map, SAW raster map)". This was used in order to combine the two maps into one map that is called the final comparison map. The resulting map from this process included number of pixels for each class and the combine number of raster categories for SAW and AHP, as well as the corresponding ratios for each class using for the matching purpose (Table 4). The similar combine number of raster categories for SAW and $\operatorname{AHP}[(1,1),(2,2),(3,3)$ and $(4,4)]$ was considered matching to their numbers of pixels that resulted from both methods. The different combine number of raster categories for SAW and AHP $[(1,2),(1,3),(2,1),(2,3),(2,4),(3,1),(3,2),(3,4)$, $(4,2)$ and $(4,3)]$ was considered as no matching. The percentage of raster values for the matching and non- matching classes is shown in Fig. 7. The final comparison map that resulted from the combination between both maps using the two methods as mentioned above was reclassified, and then the classes which have the similar output number of raster classes, their pixels were merged to produce the category of matching areas. Other classes were merged in category of non-matching (Fig. 8). The percentages of matching pixels in comparison map are $77.8 \%$ (in blue), while the percentage of the non-matching pixels is $22.2 \%$ (yellow).

\section{Result and discussion}

After identifying the weights for all the criteria through two methods (AHP and SAW), the Map Algebra tool in GIS was used to sum a cell-by-cell for the raster layers of these criteria which were place on top of each other. The result of this process produced two of the final output maps of suitability of candidate sites for landfill. Then, the comparison was performed between the two final output maps (one using SAW and the other using AHP method).

Each final output map was divided into five categories according to the suitability of the selected landfill sites. These categories were: unsuitable, moderately suitable, suitable, most suitable and the excluded areas (urban centers, villages, rivers, archeological sites and industrial areas.

The expected population in Al-Musayiab Qadhaa in 2030 is 618,274 inhabitants calculated according to the present population growth rate. The solid waste quantity expected at that year is 193,865 tonne. The cumulative quantity of solid waste expected from 2020 to 2030 was calculated according to Chabuk et al. (2015) and it was 1764,729 tonne. The waste density in the waste disposal 
Fig. 6 Suitability index and number of pixels resulting from the two maps

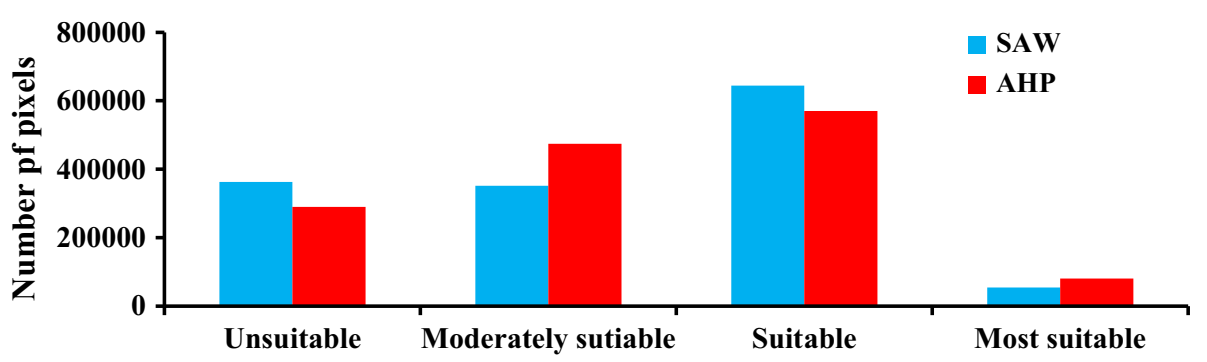

Suitability index

Table 4 The results of combining two maps resulted from (SAW) and (AHP) methods

\begin{tabular}{|c|c|c|c|c|c|}
\hline Value & Count & Raster category (SAW) & Raster category (AHP) & Corresponding pixels ratios & Classification \\
\hline 1 & 50,762 & (US) 1 & (US) 1 & 3.6034 & Matching \\
\hline 2 & 3302 & (US) 1 & $(\mathrm{MOS}) 2$ & 0.2344 & Non-matching \\
\hline 3 & 7 & (US) 1 & (S) 3 & 0.0005 & Non-matching \\
\hline 4 & 29,004 & $(\mathrm{MOS}) 2$ & (US)1 & 2.0589 & Non-matching \\
\hline 5 & 311,537 & $(\mathrm{MOS}) 2$ & $(\mathrm{MOS}) 2$ & 22.115 & Matching \\
\hline 6 & 10,317 & $(\mathrm{MOS}) 2$ & (S) 3 & 0.7323 & Non-matching \\
\hline 7 & 24 & $(\mathrm{MOS}) 2$ & (MS) 4 & 0.0017 & Non-matching \\
\hline 8 & 214 & (S) 3 & (US) 1 & 0.0152 & Non-matching \\
\hline 9 & 157,203 & (S) 3 & $(\mathrm{MOS}) 2$ & 11.16 & Non-matching \\
\hline 10 & 464,734 & (S) 3 & (S) 3 & 32.9898 & Matching \\
\hline 11 & 20,495 & (S) 3 & (MS) 4 & 1.4548 & Non-matching \\
\hline 12 & 573 & (MS) 4 & $(\mathrm{MOS}) 2$ & 0.0401 & Non-matching \\
\hline 13 & 91,779 & (MS) 4 & (S) 3 & 6.5151 & Non-matching \\
\hline 14 & 268,767 & (MS) 4 & (MS) 4 & 19.0788 & Matching \\
\hline
\end{tabular}

US unsuitable index; $M O S$ moderately suitable index; $S$ suitable index; $M S$ most suitable index category

Fig. 7 The percentages of raster values of comparison map's classes

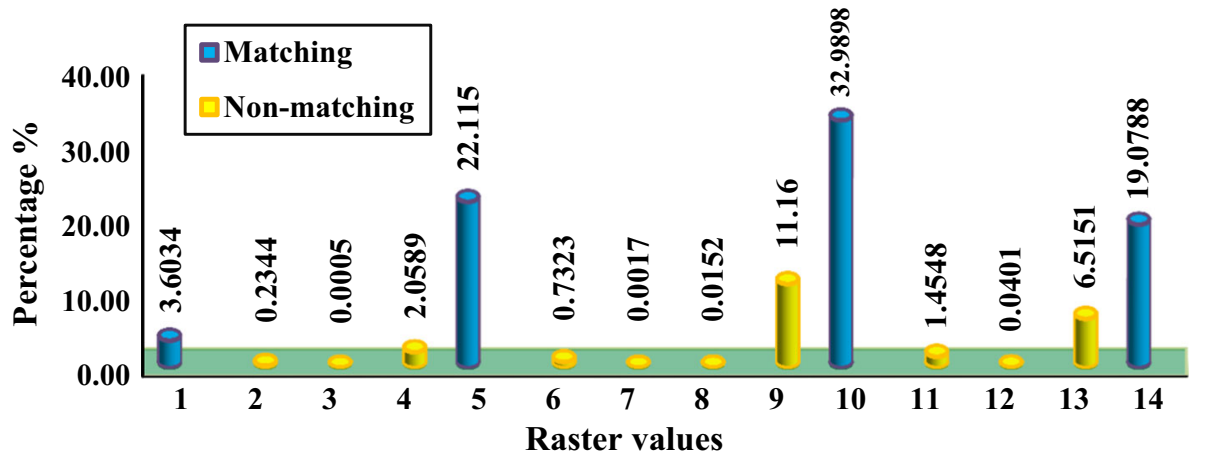

sites is $450 \mathrm{~kg} / \mathrm{m}^{3}$ in Al-Musayiab Qadhaa according to Iraqi Ministry of Municipalities and Public Works (2015). Consequently, the volume of waste and cumulative waste are 430,811 and $3921,620 \mathrm{~m}^{3}$ respectively. The groundwater depth from a ground surface in Al-Musayiab Qadhaa is shallow.

Therefore, the average depth to the groundwater in the candidate sites that resulted from this study was adopted as $2 \mathrm{~m}$. According to this condition, the area of the candidate site required to accommodate the cumulative quantity of solid waste generated from 2020 to 2030 was found to be $1.961 \mathrm{~km}^{2}$.

After the process of comparison, two candidate landfill sites were selected that fulfill the requirements. These sites are assigned in numbers ( 1 and 2). The area of site No. 1 is $7.965 \mathrm{~km}^{2}\left(32^{\circ} 48^{\prime} 39^{\prime \prime} \mathrm{N}\right.$, and longitude $\left.44^{\circ} 8^{\prime} 59^{\prime \prime} \mathrm{E}\right)$, whereas the area of site No. 2 is $5.952 \mathrm{~km}^{2}$ (latitude $33^{\circ} 0^{\prime}$ $14^{\prime \prime} \mathrm{N}$, and longitude $44^{\circ} 6^{\prime} 46^{\prime \prime} \mathrm{E}$ ) (Fig. 9). 


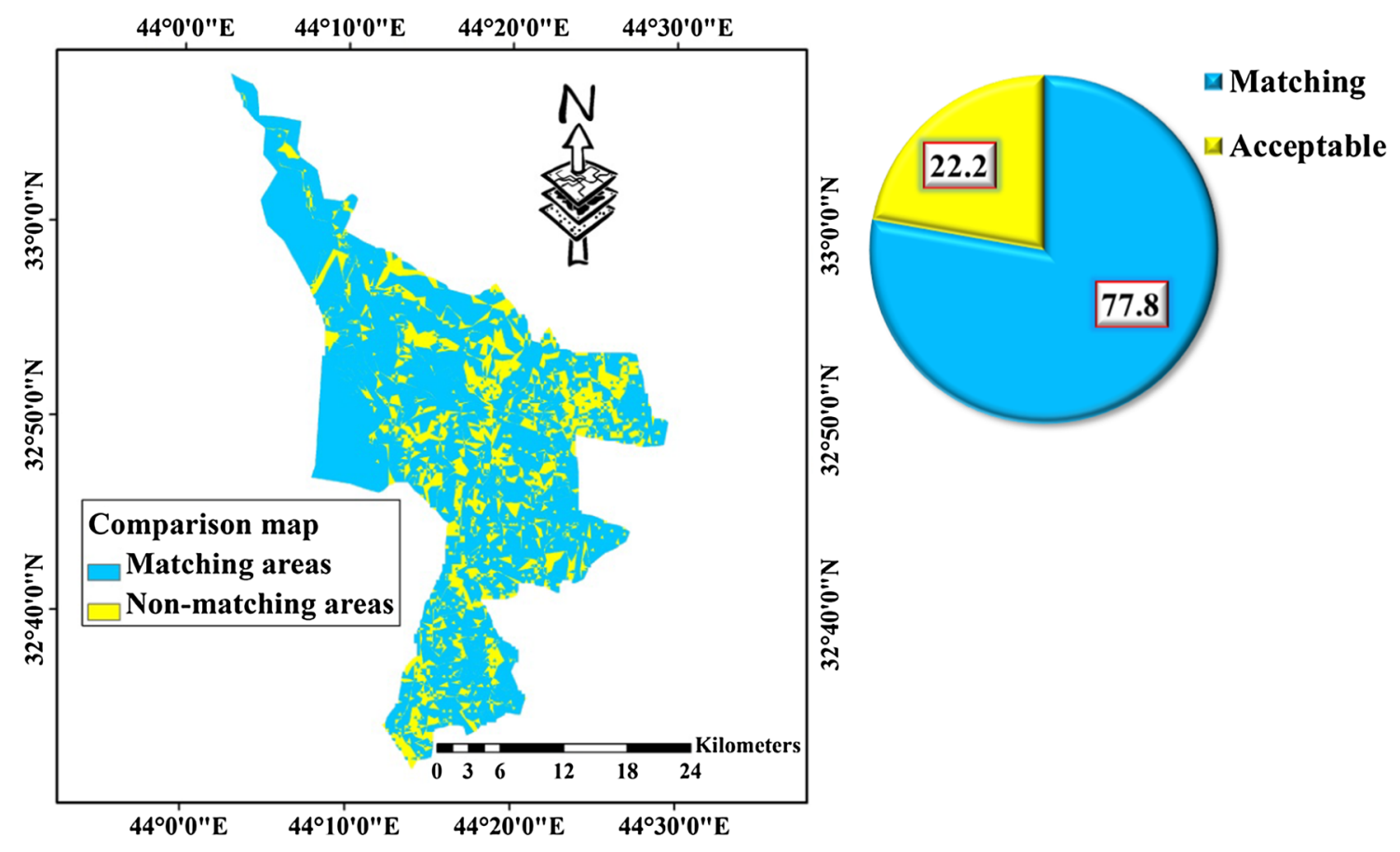

Fig. 8 The comparison map of matching and non-matching areas between AHP and SAW methods and its percentages

\section{Conclusions}

In recent years, the increase of the quantity of generated solid waste in Al-Musayiab Qadhaa and locating suitable landfill site according to scientific and environmental criteria made the local authorities pay great attention to this matter. To find the best suitable solid waste landfill site in this study, 15 layers for different criteria (groundwater depth, rivers, soil types; agriculture land use, land use, elevation, slope, gas pipelines, oil pipelines, power lines, roads, railways, urban centers, villages and archeological sites) were used in the process of analysis in order to determine the most suitable candidate solid waste landfill site. These criteria were entered in GIS environment.

The simple additive weighting and the analytical hierarchy process were used to select a suitable candidate landfill site in the studied area through deriving the weight to each criterion that was entered in GIS. After the completion of the analysis, two of the final output maps were produced from the two methods used.

The percentages of matching pixels in the comparison map, which resulted from combining the final maps of AHP and SAW using the spatial analysis tool "Map Algebra" within GIS, were $77.8 \%$, while the non-matching pixels were $22.2 \%$.

Finally, two of candidates' sites were identified for landfill among several sites in the category of the most suitable in the final map. These sites were checked on the satellite images (2011) of Babylon Governorate to make

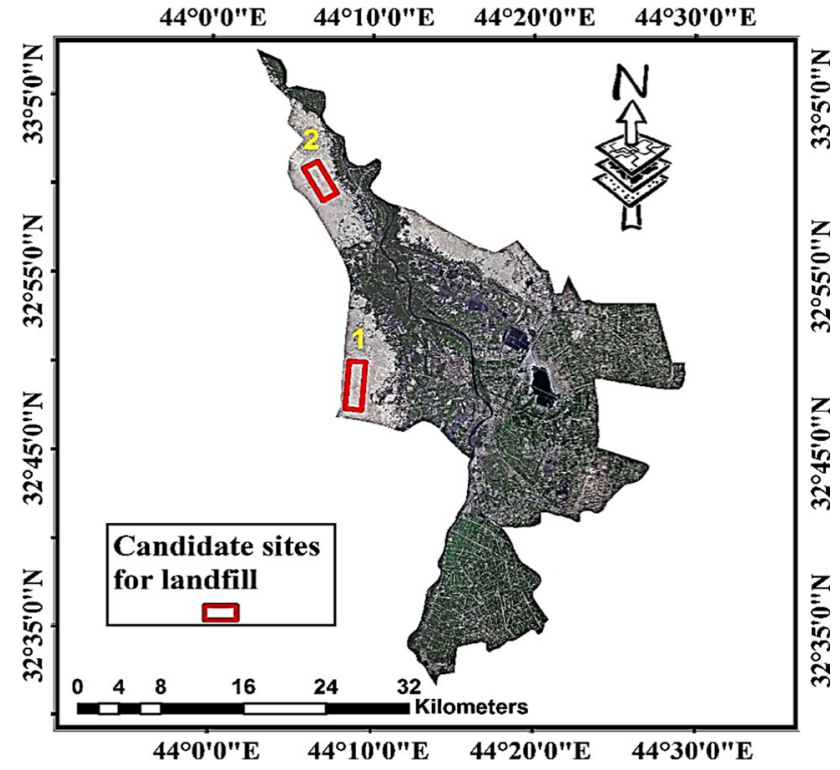

Fig. 9 The candidate sites for landfill in Al-Musayiab Qadhaa

sure that these sites are suitable for landfill. Generally, these sites satisfy the minimum requirements of the landfill sites.

The area of a site No. 1 and 2 are 7.965 and $5.952 \mathrm{~km}^{2}$, respectively. The expected solid waste for the period 2020-2030 is 1764,729 tonne based on present waste generation and population growth rate. This quantity requires an area of $1.961 \mathrm{~km}^{2}$, and the suggested candidate sites can well accommodate such waste. 
Acknowledgements This work was carried out at Lulea University of Technology, Lulea, Sweden, and Iraqi Ministry of Higher Education.

Open Access This article is distributed under the terms of the Creative Commons Attribution 4.0 International License (http://crea tivecommons.org/licenses/by/4.0/), which permits unrestricted use, distribution, and reproduction in any medium, provided you give appropriate credit to the original author(s) and the source, provide a link to the Creative Commons license, and indicate if changes were made.

\section{References}

Afshari A, Mojahed M, Yusuff RM (2010) Simple Additive Weighting approach to Personnel Selection problem. Int J Innov Manag Technol 1:511-515

Buringh P (1960) Soils and soil conditions in Iraq. The Ministry of Agriculture, Baghdad, p 337

Chabuk A, Al-Ansari N, Hussain HM, Knutsson S, Pusch R (2015) Present status of solid waste management at Babylon Governorate, Iraq. Engineering 7:408-423

Chabuk A, Al-Ansari N, Hussain HM, Knutsson S, Pusch R (2016) Landfill site selection using geographic information system (GIS) and AHP: a case study Al-Hillah Qadhaa, Babylon, Iraq. Waste Manag Res 34:427-437

Chang C, Wu C, Lin C, Lin H (2007) Evaluating digital video recorder systems using analytic hierarchy and analytic network processes. Inf Sci 177:3383-3396

Charnpratheep K, Zhou Q, Garner B (1997) Preliminary landfill site screening using fuzzy geographical information systems. Waste Manag Res 15:197-215

Coyle G (2004) The Analytic Hierarchy Process (AHP). Pearson Education Limited, Essex. http://www.booksites.net/download/ coyle/student_files/AHP_Technique.pdf. Accessed 21 Sept 2015

Delgado OB, Mendoza M, Granados EL, Geneletti D (2008) Analysis of land suitability for the siting of inter-municipal landfills in the Cuitzeo Lake Basin, Mexico. Waste Manag 28:1137-1146

Demesouka O, Vavatsikos A, Anagnostopoulos K (2013) Suitability analysis for siting MSW landfills and its multicriteria spatial decision support system: method, implementation and case study. Waste Manag 33:1190-1206

Effat HA, Hegazy MN (2012) Mapping potential landfill sites for North Sinai cities using spatial multicriteria evaluation. Egypt J Remote Sens Space Sci 15:125-133

Ersoy H, Bulut F (2009) Spatial and multi-criteria decision analysisbased methodology for landfill site selection in growing urban regions. Waste Manag Res 27:489-500

Eskandari M, Homaee M, Mahmodi S (2012) An integrated multi criteria approach for landfill siting in a conflicting environmental, economical and socio-cultural area. Waste Manag 32:1528-1538

Gupta R, Kewalramani MA, Ralegaonkar RV (2003) Environmental impact analysis using fuzzy relation for landfill siting. J Urban Plan Dev 129:121-139

Hussain MH (2004) Assessment of groundwater vulnerability in an alluvial interfluve using GIS. Ph.D. Thesis, Indian Institute of Technology, Roorkee

Iraqi Ministry of Municipalities and Public Works (2009) Structural Plan of Babylon Governorate. The Directorate General of Urban Planning, Information Analysis Report (Revised), stage 2. 223p

Iraqi Ministry of Municipalities and Public Works (2011) Internal reports, Directorate of Sewage Babylon

Iraqi Ministry of Municipalities and Public Works (2015) Records of Directorate of Babylon Municipalities, Babylon
Iraqi Ministry of Planning (2015) Records of Directorate of Census Babylon. Iraqi Ministry of Planning, Baghdad

Iraqi Ministry of Water Resources (1990) State commission of survey

Iraqi Ministry of Water Resources (2015) Internal reports, General commission for groundwater

Isalou A, Zamani V, Shahmoradi B, Alizadeh H (2013) Landfill site selection using integrated fuzzy logic and analytic network process (F-ANP). Environ Earth Sci 68:1745-1755

Kara C, Doratli N (2012) Application of GIS/AHP in siting sanitary landfill: a case study in Northern Cyprus. Waste Manag Res 30:966-980

Kontos TD, Komilis DP, Halvadakis CP (2003) Siting MSW landfills on Lesvos island with a GIS based methodology. Waste Manag Res 21:262-277

Lin H, Kao J (1999) Enhanced spatial model for landfill siting analysis. J Environ Eng 125:845-851

Lober DJ (1995) Resolving the siting impasse: modeling social and environmental locational criteria with a geographic information system. J Am Plan Assoc 61:482-495

Nas B, Cay T, Iscan F, Berktay A (2010) Selection of MSW landfill site for Konya, Turkey using GIS and multi-criteria evaluation. Environ Monit Assess 160:491-500

Rezaei-Moghaddam K, Karami EA (2008) Multiple criteria evaluation of sustainable agricultural development models using AHP. Environ Dev Sustain 10:407-426

Saaty TL (1980) The analytic hierarchy process: planning, priority setting, resources allocation. McGraw, New York

Sadek S, El-Fadel M, Freiha F (2006) Compliance factors within a GIS-based framework for landfill siting. Int $\mathrm{J}$ Environ Stud 63:71-86

Sener B (2004) Landfill site selection by using geography information System. Master's Dissertation, Middle East Technical University

Şener B, Suzen LM, Doyuran V (2006) Landfill site selection by using geographic information systems. Environ Geol 49:376-388

Şener Ş, Sener E, Karagüzel R (2011) Solid waste disposal site selection with GIS and AHP methodology: a case study in Senirkent-Uluborlu (Isparta) Basin, Turkey. Environ Monit Assess 173:533-554

Sharifi M, Mosslem HM, Vessali E, Mosstafakhani P, Taheri K, Shahoie S, Khodamoradpour M (2009) Integrating multi-criteria decision analysis for a GIS-based hazardous waste landfill sitting in Kurdistan Province, Western Iran. Waste Manag 29:2740-2758

Siddiqui MZ, Everett JW, Vieux BE (1999) Landfill siting using geographic information systems: a demonstration. J Environ Eng 122:515-523

Solnes J (2003) Environmental quality indexing of large industrial development alternatives using AHP. Environ Impact Assess Rev 23:283-303

Teknomo K (2006) Analytic Hierarchy Process (AHP) Tutorial. Revoledu.com. http://www.thecourse.us/5/library/AHP/AHP_ Tutorial.pdf.World Digital Library. 2013. Accessed 21 Sept 2015

Uyan M (2014) MSW landfill site selection by combining AHP with GIS for Konya, Turkey. Environ Earth Sci 71:1629-1639

Wang G, Qin L, Li G, Chen L (2009) Landfill site selection using spatial information technologies and AHP: a case study in Beijing, China. J Environ Manag 90:2414-2421

Yesilnacar MI, Cetin H (2008) An environmental geomorphologic approach to site selection for hazardous wastes. Environ Geol 55:1659-1671

Yildirim V (2012) Application of raster-based GIS techniques in the siting of landfills in Trabzon Province, Turkey: a case study. Waste Manag Res 30:949-960 